\title{
Identification and characterization of a gene that controls colony morphology and auto-aggregation in Escherichia coli $\mathrm{K12}$
}

\author{
Simon R. Warne, ${ }^{1 *} \dagger$ Jennifer M. Varley, ${ }^{2}$ Graham J. Boulnois ${ }^{3}$ and \\ Michael G. NORTON ${ }^{1} \ddagger$ \\ ${ }^{1}$ Warren Spring Laboratory, Gunnels Wood Road, Stevenage, Herts SG1 2BX, UK \\ ${ }^{2}$ Department of Biochemistry, University of Leicester, Leicester LE1 7RH, UK \\ ${ }^{3}$ Department of Microbiology, University of Leicester, Leicester LE1 9HN, UK
}

(Received 26 September 1989; revised 21 November 1989; accepted 30 November 1989)

\begin{abstract}
Many Escherichia coli K12 strains undergo switching between two forms which differ in a number of surface properties including colony morphology and the ability to auto-aggregate. This paper describes the identification of a gene which appears to play a part in controlling this switching phenomenon. This gene has been designated mor and is located at 89 minutes on the $E$. coli chromosome map between the $\arg E C B H$ operon and the trm $A$ gene. By manipulation of this gene it is possible to overcome the switching of surface properties and fix a strain in one form or the other. The mor gene has been cloned and its DNA sequence determined. The putative protein sequence shows a high level of homology with four regulatory genes, the $i l v Y, \operatorname{cys} B$ and $l y s R$ genes from $E$. coli and the metR gene from Salmonella typhimurium. It has also been shown that the mor gene is autoregulated at the transcriptional level.
\end{abstract}

\section{Introduction}

Diderichsen (1980) described the existence in many Escherichia coli $\mathrm{K} 12$ strains of two interconvertible forms, which can be distinguished on the basis of colony morphology and their ability to form cell clumps in liquid media. One form, Form 1, is characterized by dull colonies with an irregular shape. This form also undergoes auto-aggregation in liquid culture and the cell clumps sediment to form a cell pellet when a shaken culture is left to stand. The other form, Form 2, is characterized by round, glossy colonies that tend to be smaller than the dull colonies. This form does not undergo auto-aggregation in liquid culture. Another feature which distinguishes the two forms is that Form 2 produces type 1 pili (fimbriae) on its surface, when grown in a static liquid culture, whereas Form 1 is not piliated. The rate of switching from Form 1 to Form 2 differs from the rate of switching from Form 2 to Form 1. When a colony in Form 1 is restreaked on an agar plate about $10 \%$ of colonies will have switched to Form 2 .

† Present address: Medical Research Council, 20 Park Crescent, London W1N 4AL, UK.

$\ddagger$ Present address: Director, Parliamentary Office of Science and Technology, 2 Little Smith's Street, London SW1, UK.
When a colony in Form 2 is restreaked about $3 \%$ of colonies will have switched to Form 1.

Diderichsen (1980) identified a gene which is involved in controlling the switching of a strain between these two forms. He designated this gene $f u$, and mapped it to a position around 43 minutes on the $E$. coli chromosome. In addition to his work on the $f u$ gene, Diderichsen also noted that when a segment in the 89 minute region of the chromosome is deleted from a strain exhibiting switching between Forms 1 and 2, this fixes the strain permanently in Form 1 .

This paper describes work in which we have investigated further the genetic basis for the observation that a deletion in the 89 minute region can fix a strain in Form 1. This work has led to the characterization of a previously unidentified $E$. coli gene which we have designated mor. This gene is involved in the control of a number of surface properties, including colony morphology and auto-aggregation.

\section{Methods}

Bacterial strains and culture conditions. The $E$. coli $\mathrm{K} 12$ strains used in this study are shown in Table 1. LB broth and LB agar (Miller, 1972) were generally used for culture growth. Selection of auxotrophic markers was done using M9 medium (Miller, 1972) with appropriate supplements. $\mathrm{Lac}^{+}$bacteria were detected using MacConkey agar 
Table 1. Bacterial strains used in this work

\begin{tabular}{|c|c|c|}
\hline Strain & Genotype/phenotype & Source \\
\hline BD1302 & metB $\Delta\left(p p c\right.$ argECBH mor) relA spoT $\left(\lambda^{+}\right) H f r P 4 X$ & B. Diderichsen, \\
\hline BD1512 & lys A metE proB purE thi trp str supE tsx lac & Novo Ltd, Denmark \\
\hline JM108 & thi endA hsdR rec $A$ gyrA supE relA $\triangle($ lac-proAB $)$ & $\begin{array}{l}\text { R. Schmitt } \\
\text { University of Regensburg, FRG }\end{array}$ \\
\hline SW 1007 & $\operatorname{argE}$ aroD his $\Delta($ proA-gpt $)$ thi shiA tsx gal mtl xyl recA $\mathrm{Tc}^{\mathrm{R}}$ & $\begin{array}{l}\text { Constructed by transducing } \\
\text { BD1712 (source: B. Diderichsen) } \\
\text { with a recA mutation }\end{array}$ \\
\hline MC1022 & araD139 $\Delta($ ara,leu $) 7697 \Delta($ lacZ)M15 galU galK strA & $\begin{array}{l}\text { C. Thomas } \\
\text { University of Birmingham, UK }\end{array}$ \\
\hline N2026 & $\begin{array}{l}\text { recB21 recC22 sbcB15 sbcC201 thi-1 proB48 his-4 argE3 } \\
\text { lac13 lacZ118 mtl-1 xyl-5 supE44 rpsL31 }\end{array}$ & $\begin{array}{l}\text { R. Lloyd } \\
\text { University of Nottingham, UK }\end{array}$ \\
\hline SW1066 & $\begin{array}{l}\text { recB21 recC22 sbcB15 sbcC201 thi-1 proB48 his-4 argE3 } \\
\text { lacI3 lacZ118 mtl-1 xyl-5 supE44 rpsL31 mor-lacZ } \mathrm{Km}^{\mathrm{R}}\end{array}$ & \\
\hline SW1099 & $\begin{array}{l}\operatorname{araD139} \Delta(\text { ara,leu }) 7697 \Delta(\text { lacZ }) \mathrm{M} 15 \text { galU galK strA thi } \\
\operatorname{argE~} \text { mor-lacZ } \mathrm{Km}^{\mathrm{R}}\end{array}$ & This work \\
\hline
\end{tabular}

(Oxoid). $\mathrm{Ap}^{\mathrm{R}}, \mathrm{Tc}^{\mathrm{R}}, \mathrm{Cm}^{\mathrm{R}}$ and $\mathrm{Km}^{\mathrm{R}}$ markers were selected using $50 \mu \mathrm{g}$ ampicillin $\mathrm{ml}^{-1}, 20 \mu \mathrm{g}$ tetracycline $\mathrm{ml}^{-1}, 25 \mu \mathrm{g}$ chloramphenicol $\mathrm{ml}^{-1}$ and $40 \mu \mathrm{g}$ kanamycin $\mathrm{ml}^{-1}$ respectively. All cultures were grown at $37^{\circ} \mathrm{C}$ and liquid cultures were shaken at 200 r.p.m. in an orbital incubator.

P1 transduction. Strain construction was done by the method of Miller (1972).

Settling tests. The formation of cell aggregates was generally monitored by settling tests. Each test involved inoculating $5 \mathrm{ml}$ of LB broth in a $30 \mathrm{ml}$ plastic Universal bottle (Sterilin), incubating in an orbital shaker for $15 \mathrm{~h}$ and then leaving the bottle to stand. With a strain such as BD1302, which exhibits rapid sedimentation, up to $60 \%$ of the cells would have settled to form a distinct pellet within $1 \mathrm{~h}$. Following prolonged standing $(6 \mathrm{~h})$, the medium above the pellet would be almost clear. The size of the cell aggregates which cause this sedimentation was measured using both laser light scattering (Malvern model $2600 \mathrm{C}$ ) and a Coulter multisizer. The aggregates were between 3 and $6 \mu \mathrm{m}$ across.

Inoculum-size-sensitivity. This was monitored by plating $3 \times 10^{6}$ cells on a LB-agar plate. A standard strain would give confluent growth, while an inoculum-size-sensitive strain would give small patches of growth and a few single colonies. If $3 \times 10^{4}$ cells were plated no growth would be obtained with an inoculum-size-sensitive strain.

Cosmid cloning and DNA manipulation. Cosmid cloning was done with the vector pEMBLcos4 using the method of Hadfield (1987). Chromosomal DNA was partially digested with. Sau $3 A$ and the resulting fragments ligated with the cosmid arms formed by digesting pEMBLcos4 with BamHI and PvuII. The $\lambda$ packaging mix used was supplied by Amersham. Plasmid DNA was generally prepared by the method of Birnboim \& Doly (1979) although in some cases additional phenol extraction steps were done.

Transposon mutagenesis. The target plasmid (PSRW220 or pSRW226) was transformed into the strain JM108(pRU870) with selection for ampicillin and chloramphenicol resistance. Plasmid pRU870 contains the $\mathrm{Cm}^{\mathrm{R}}$ transposon $\mathrm{Tr} 1737 \mathrm{Cm}$ (Ubben \& Schmitt, 1987) and is compatible with plasmids with pMB1-based replicons such as pSRW220 or pSRW226. Following transformation single colonies were left for approximately 2 weeks at room temperature. Whole colonies were then inoculated inte $5 \mathrm{ml}$ of LB broth, grown overnight and plasmid DNA isolated from a $1 \mathrm{ml}$ sample. Next a third of the DNA from each isolation was transformed into $\mathrm{MC1022}$, and selection was done on LB agar containing ampicillin and chloramphenicol. One transformant from each transformation was then taken and plasmid DNA purified. At this stage a check was made to ensure that an insertion derivative of the target plasmid had been isolated and that there had not been a double transformation resulting, for example, in the presence of unmodified plasmid alongside the insertion derivative. In each case the position of the transposon insertion was determined to an accuracy of about $100 \mathrm{bp}$ by restriction mapping.

In $T n 1737 \mathrm{Cm}$ the lac $Z$ coding sequence is located at one end (Ubben \& Schmitt, 1987). There is no promoter for $l a c Z$ within the transposon and so $\beta$-galactosidase is only produced if the transposon becomes inserted downstream from a promoter in the correct orientation. The formation of transcriptional fusions with lac $Z$ was detected using MacConkey agar plates.

DNA sequencing. This was done using the methods described by Varley \& Boulnois (1984) and Walker et al. (1987). Both strands were sequenced.

Integration of linear DNA fragments into the chromosome. This was done as described by Jasin \& Schimmel (1984).

Determination of $\beta$-galactosidase activity. The method of Miller (1972) was used; activities were calculated in arbitrary units.

\section{Results}

Cloning of a gene from the 89 minute region of the E. coli chromosome which is involved in controlling colony morphology and auto-aggregation

The deletion in strain BD1302 (Diderichsen, 1980) that causes it to be fixed in Form 1 removes a segment of DNA that includes the $\arg E C B H$ operon. Therefore, in order to isolate DNA from this region of the chromosome, cosmid cloning was done using the $\mathrm{Arg}^{-}$strain SW1007 as the recipient and initial selection was for 

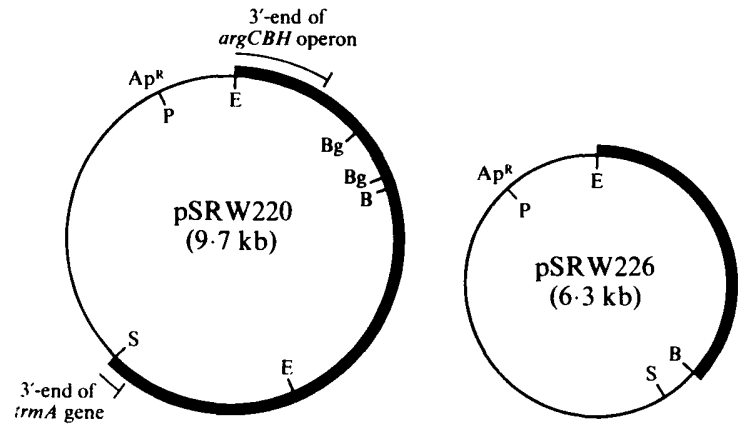

Fig. 1. Structure of the plasmids pSRW220 and pSRW226. Chromosomally derived DNA; -, pBR322-derived DNA. E, B, Bg, P and $\mathrm{S}$ represent the sites for the restriction enzymes EcoRI, BamHI, $B g I I I, P s t I$ and $S a I I$ respectively. Ap ${ }^{\mathrm{R}}$ represents the gene for ampicillin resistance.

$\mathrm{Arg}^{+}$clones. The chromosomal DNA used for this cosmid bank was isolated from strain BD1512 which undergoes switching between Forms 1 and 2. Cosmid DNA from one of the $\mathrm{Arg}^{+}$clones that was obtained was then cut with HindIII and SalI and the fragments produced were ligated with pBR322 DNA that had been cut with HindIII and SalI. The resulting plasmids were then screened for the ability to complement the genetic defect in strain BD1302 that causes it to be fixed in Form 1 . This was done by transforming the plasmids into BD1302 and by using settling tests to identify plasmids capable of preventing the rapid sedimentation of cells from a static suspension that is characteristic of this strain. One such plasmid was identified and designated pSRW220 (Fig. 1). In settling tests with BD1302(pSRW220) all of the cells remained in suspension after $1 \mathrm{~h}$ in contrast to the situation with BD1302 where up to $60 \%$ of the cells sedimented within this time.

pSRW220 contained a $6.0 \mathrm{~kb}$ insert of chromosomal DNA (Fig. 1). Comparison was made with previous studies in which restriction mapping of the chromosomal region including $\operatorname{argECBH}$ and $\operatorname{trm} A$ was done $(\mathrm{Ny} \&$ Björk, 1980; Heller et al., 1985). From these data it was concluded that the $6.0 \mathrm{~kb}$ fragment in pSRW220 contained the $3^{\prime}$-end of the $\arg C B H$ transcription unit, the 3 '-end of the trmA gene and the whole of the region between these two loci.

Further subcloning from pSRW220 revealed that when the $2.3 \mathrm{~kb}$ EcoRI-BamHI fragment from pSRW220 was inserted between the EcoRI and BamHI sites of pBR322 to form pSRW226 (Fig. 1), this smaller plasmid also complemented the genetic defect in strain BD1302 as judged by its ability to prevent the rapid sedimentation of cells from a static suspension. Close examination of the colony morphology of BD1302(pSRW226) revealed that all the colonies were

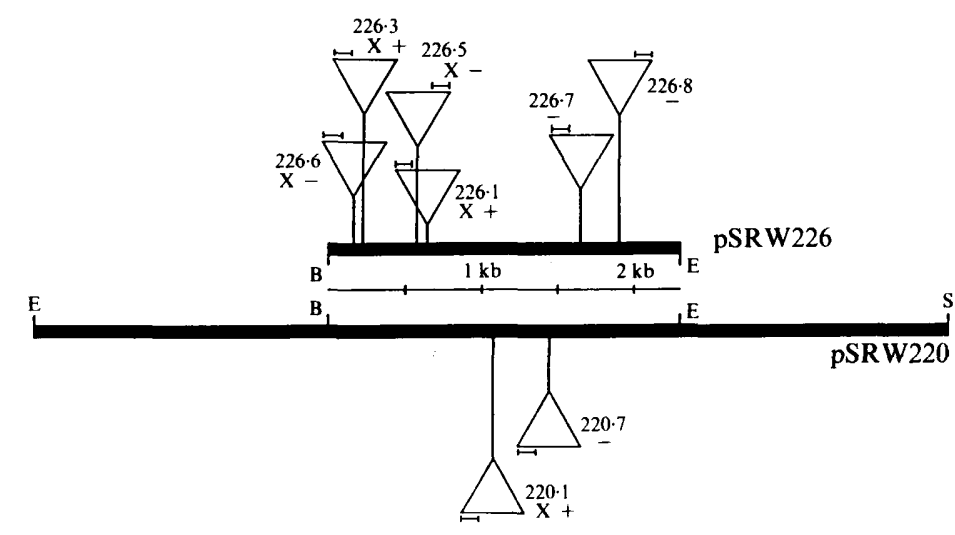

Fig. 2. Location and effect of $\mathrm{Tn} 1737 \mathrm{Cm}$ insertions into the chromosomally derived DNA of pSRW220 and pSRW226. Those insertions which caused insertional inactivation of the mor gene are marked with an X. The orientation of each insert is shown by indicating the position of the $l a c Z$ coding sequence in each case. Those insertion derivatives in which the lac $Z$ sequence was transcribed as judged by the observation of a red colouration on MacConkey agar are marked with a + . Those insertion derivatives in which there was no detectable transcription of the $l a c Z$ gene are marked with a - . B, E and $S$ indicate the sites for the restriction enzymes BamHI, EcoRI and SalI respectively.

glossy and that no dull colonies were produced. It thus became apparent that this strain does not undergo switching and is fixed in Form 2. Furthermore the introduction of pSRW226 into BD1302 was found to overcome the inoculum-size-sensitivity of this strain.

\section{Identification of the mor gene by transposon mutagenesis}

To locate more accurately the position of the gene which had been cloned, transposon mutagenesis of both pSRW220 and pSRW226 was done using Tn $1737 \mathrm{Cm}$ (Ubben \& Schmitt, 1987). The results of this transposon mutagenesis are shown in Fig. 2. Insertion derivatives pSRW226.1, 226.3, 226.5, 226.6 and 220.1 all exhibited insertional inactivation and failed to complement the deletion in BD1302. This was shown by the observation of rapid sedimentation of cells in settling tests. Further checks on colony morphology revealed that the dull phenotype was exhibited. The positions at which insertion had occurred were taken to define the position of the gene whose introduction into BD1302 on a plasmid fixes the strain in Form 2. This gene was designated mor (colony morphology). A transcriptional analysis of this region was made possible by the presence of the lac $Z$ coding sequence at one end of $T n 1737 \mathrm{Cm}$. Two interesting points emerged from testing the different insertion derivatives for expression of $\beta$-galactosidase. First, the detection of $\beta$-galactosidase activity with pSRW226.3, 226.1 and 220.1 indicated that the direction 


\begin{tabular}{|c|c|c|c|c|c|}
\hline 1 & GGATCCTGGA & GATCCGCAAA & AGTTCACGTT & GGCTTTAGTT & ATTCGAGTTG \\
\hline 51 & AGAAACTCTC & GAAACGGGCA & GTGACTTCAA & GGGTTAAAAG & AGGTGCCGCT \\
\hline 101 & CCGTTTCTGT & GAGCAATTAT & CAGTCAGAAT & GCTTGATAGG & GATAATCGTT \\
\hline 151 & CATTGCTATT & CTACCTATCG & CCATGAACTA & TCGTGGCGAT & $\begin{array}{l}\text { S D } \\
\text { GGAGGATGGA }\end{array}$ \\
\hline 201 & TA $\overline{A T G A A T A T}$ & TCGTGATCTT & GAGTACCTGG & TGGCATTGGC & TGAACACCGC \\
\hline 251 & CATTTTCGGC & GTGCGGCAGA & TTCCTGCCAC & GTTAGCCAGC & CGACGCTTAG \\
\hline 301 & CGGGCAAATT & CGTAAGCTGG & AAGATGAGCT & GGGCGTGATG & TTGCTGGAGC \\
\hline 51 & GGACCAGCCG & TAAAGTGTTG & TTCACCCAGG & CGGGAATGCT & GCTGGTGGAT \\
\hline 401 & CAGGCGCGTA & CCGTGCTGCG & TGAGGTGAAA & GTCCTTAAAG & AGATGGCAAG \\
\hline 51 & CCAGCAGGGC & GAGACGATGT & CCGGACCGCT & GCACATTGGT & TTGATTCCCA \\
\hline 501 & CAGTTGGACC & GTACCTGCTA & CCGCATATTA & TCCCTATGCT & GCACCAGACC \\
\hline 551 & TTTCCAAAGC & TGGAAATGTA & TCTGCATGAA & GCACAGACCC & ACCAGTTACT \\
\hline 01 & GGCGCAACTG & GACAGCGGCA & AACTCGATTG & CGTGATCCTC & GCGCTGGTGA \\
\hline 651 & AAGAGAGCGA & AGCATTCATT & GAAGTGCCGT & TGTTTGATGA & GCCAATGTTG \\
\hline 1 & CTGGCTATCT & ATGAAGATCA & CCCGTGGGCG & AACCGCGAAT & GCGTACCGAT \\
\hline 751 & GGCCGATCTG & GCAGGGGAAA & AACTGCTGAT & GCTGGAAGAT & GGTCACTGTT \\
\hline 801 & TGCGCGATCA & GGCAATGGGT & TTCTGTTTTG & AAGCCGGGGC & GGATGAAGAT \\
\hline 51 & ACACACTTCC & GCGCGACCAG & CCTGGAAACT & CTGCGCAACA & TGGTGGCGGC \\
\hline 01 & AGGTAGCGGG & ATCACTTTAC & TGCCAGCGCT & GGCTGTGCCG & CCGGAGGCCA \\
\hline $95 !$ & AACGCGATGG & GGTTGTTTAT & CTGCCGTGCA & TTAAGCCGGA & ACCACGCCGC \\
\hline 1 & ACTATTGGCC & TGGTTTATCG & TCCTGGCTCA & CCGCTGCGCA & GCCGCTATGA \\
\hline & GCAGCTGGCA & GAGGCCATCC & GCGCAAGAAT & $\begin{array}{c}\text { GGATGGCCAT } \\
1\end{array}$ & AAAG \\
\hline & TTTTAAAACA & GGCGGTT $\overline{T A A}$ & ACCGTTTAAC & GCAGCTACCC & $\overrightarrow{\text { GATAGCTTCG }}$ \\
\hline & CCATCGTCGG & $\overline{\text { GTAGTTAAAG }}$ & $\overrightarrow{\text { GTGGTGTTGA }}$ & CGAAGTACTC & AATAGTGTTG \\
\hline & CCGCCACCTT & TCTGTTCCAT & AATCGCCTGA & CCGATATGAA & TAATTTCGGC \\
\hline & AGCGCGCTCG & CCAAAGCA & GAATACCCAG & AATCTCTTTT & GTTTCCCGAT \\
\hline & GGAACAAAAT & TTTCAGCGTG & CCCACGTTCA & TGCCGACGAT & TTGTGCGCGT \\
\hline & GCCAGATGTT & TAAACTGGGC & GCGGCCCACT & TCATATGGCA & CTTTCATTGC \\
\hline & GGTCAGCTGC & TGTTCGGTTT & TGCCCACAGA & GCTGATTTCC & GGGATGGTGT \\
\hline & AAATACCGGT & AGGGATAT & TCAATCAGAT & GTGCGGTGGC & TTCGCCTTTT \\
\hline
\end{tabular}


of transcription of the mor gene is away from the BamHI site of pSRW226 towards the EcoRI site. Second, the failure to detect transcription of $\beta$-galactosidase with pSRW226.6, even though the insert in this plasmid is in the same orientation as the insert in pSRW226.3, suggested that in the former plasmid insertional inactivation in the region of the mor promoter has occurred.

\section{Sequence of the mor gene}

The sequence of the $2 \cdot 3 \mathrm{~kb} B a m \mathrm{HI}-E c o \mathrm{RI}$ fragment of pSRW226 was determined. Fig. 3 shows the first $1.5 \mathrm{~kb}$ of this sequence starting from the BamHI site. The results obtained from the transposon mutagenesis enabled the mor gene to be readily identified. The region delimited by the transposon inserts, which brought about insertional inactivation, contained an open reading frame capable of encoding a 305 -amino-acid protein. Immediately upstream from this coding sequence was a region showing all the characteristics of an $E$. coli translation initiation site (Kozak, 1983). Moreover, a sequence showing strong homology to the consensus $E$. coli promoter sequence (Hawley \& McClure, 1983) was identified in the region where the mor gene promoter was predicted to lie following the results obtained with insertion derivative pSRW226.6.

The Swiss-Prot protein sequence data base was screened using the FASTP method of computer searching (Lipman \& Pearson, 1985) for sequences showing homology to the deduced amino acid sequence of the mor gene product. Four proteins showing a high level of homology were identified. These were the $i l v Y, \operatorname{cys} B$ and lysR proteins of $E$. coli (Wek \& Hatfield, 1986; Ostrowski et al., 1987; Stragier \& Patte, 1983) and the metR protein of Salmonella typhimurium (Plamann \& Stauffer, 1987). The percentage homologies that the putative mor gene product exhibits with these four proteins are listed in Table 2. It can be seen that ilv $Y$ shows the highest homology with $29.4 \%$ identity in a 262 amino acid overlap. This homology is illustrated in Fig. 4.

\section{Demonstration that the mor gene is autoregulated}

The observation of homology between the putative mor gene product and the regulatory proteins $i l v Y, \operatorname{cys} B, l y s R$ and $m e t R$ led to the tentative proposal that the mor protein might have a regulatory function. In order to
Table 2. Percentage identity between various members of the mor, ilv $Y$, lysR, cysB and met $R$ protein family

\begin{tabular}{lccccc}
\hline \hline & \multicolumn{5}{c}{ Percentage identity* } \\
\cline { 2 - 6 } & mor & ilv $Y$ & lysR & cysB & metR \\
\hline mor & 100 & $29.4(262)$ & $20.7(305)$ & $26.0(288)$ & $26.7(255)$ \\
ilv $Y$ & - & 100 & $21.6(292)$ & $21.4(262)$ & $26.6(252)$ \\
lysR & - & - & 100 & $22.2(257)$ & $23.0(257)$ \\
cysB & - & - & - & 100 & $22.2(257)$ \\
met $R$ & - & - & - & - & 100 \\
\hline \hline
\end{tabular}

* The length of the amino acid overlap to which each percentage identity refers is shown in parentheses.

obtain further evidence for such a proposal, it was decided to investigate whether expression of the mor gene is autoregulated. Such a regulatory mechanism has been shown to operate in the case of a number of previously characterized regulatory genes, including $l y s R$ (Stragier \& Patte, 1983) and cysB (Ostrowski et al., 1987). In order to test for autoregulation use was made of the transcriptional fusion in pSRW220.1 (see above) which has $\mathrm{Tn} 1737 \mathrm{Cm}$ inserted in such a way that the lac $Z$ coding sequence is transcribed from the mor promoter. Further transposition of $T n 1737 \mathrm{Cm}$ was prevented by removing the $\operatorname{tn} p R$ and $\operatorname{tn} p A$ transposition functions from pSRW220.1 and replacing them with the kanamycinresistance gene of $\mathrm{Tn} 5$. The resulting plasmid was designated pSRW231 and its construction is illustrated in Fig. 5. The mor-lac $Z$ fusion was then inserted into the chromosome by cutting pSRW231 with the restriction enzyme Tth111I and transforming the linear DNA into N2026 with selection for kanamycin resistance. Integration of the mor-lac $Z$ fusion into the chromosome was thus allowed to take place by homologous recombination of the DNA flanking the transcriptional fusion with the corresponding DNA in the chromosome. The strain formed in this way was designated SW1066. The morlacZ fusion was then transferred into the lac strain MC1022 by P1 transduction with selection for kanamycin resistance and the strain so formed was designated SW1099.

To test for autoregulation of the mor promoter, the level of $\beta$-galactosidase expression from the mor-lac $Z$ fusion was compared in the following three strains, SW1099(pSRW226), SW1099(pKO6) and SW1099. Plasmid pKO6 (McKenney et al., 1981) was used as a

Fig. 3. Sequence of the chromosomal region which contains the mor gene. The sequence shown starts at the BamHI site of pSRW226. The -10 and -35 boxes of the putative mor promotor are underlined as is the putative Shine-Dalgarno sequence (S-D). The open reading frame, which from the transposon mutagenesis would appear to be the mor coding sequence, lies between a start codon at position 203 and a stop codon at position 1118. Two inverted repeat sequences at the $3^{\prime}$-end of the mor gene are marked by arrows and are labelled 1 and 2. 


\begin{tabular}{|c|c|}
\hline mor & MNIRDLEYLVALAEHRHFRRAADSCHVSQPTLSGQIRKLEDELGVMLLERTSRKVLFTQA \\
\hline ilv $Y$ & 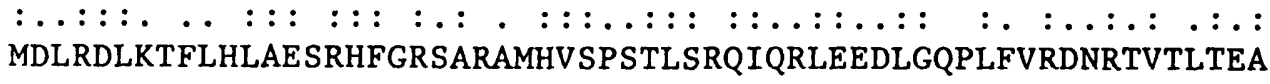 \\
\hline & 30 \\
\hline & 90 \\
\hline mor & GMLLVDQARTVLREVKVLKEMASQQGETMSGPLH IGL IPTVGPY-LLPHI IPMLHQTFPK \\
\hline$i l v Y$ & 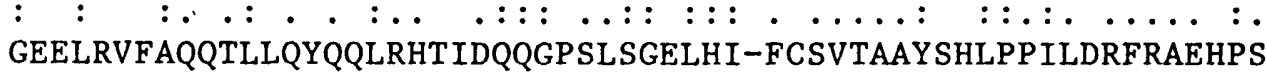 \\
\hline
\end{tabular}

90

120

150

mor LEMYLHEAQTHQLLAQLDSGKLDCVILALVKESEAF IEVPLFDEPMLLAIYEDHPWANRE

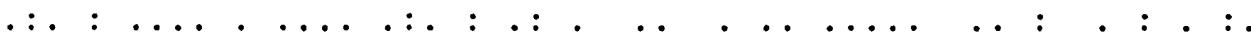
$i l v Y$ VE IKLTTGDAADAMEKVVTGEADLAIAGKPETLPGAVAF SMLENLAVVLIAPALPCPVRN 120

150

180

CVPM--ADLAGEKLLMLEDGHCLRDQAMGFCFEAGADEDTHFRATSLETLRNMVAAGSGI

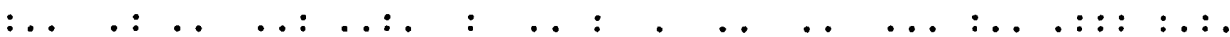
QVSVEKPDWSTVPF IMADQGPVRRRIELWFRRNKISNPMIYATVGGHEAMVSMVALGCGV 180

240

270

mor

TLLP--ALAVPPEAKRDGVVYLPCIKPEPRRTIGLVYRPGSPLRSRYEQLAEAIRARMDG

.: : : : . . : : : . : . :

ilv $Y$

ALLPEVVLENSPEPVRNRVMILERSDEKTPFELGVCAQKKRLHEPLIEAFWKILPNHK 240

270

300

mor

Fig. 4. Homology between the predicted mor amino acid sequence and the $i l v Y$ protein. Upper line, predicted amino acid sequence of mor protein ; lower line, amino acid sequence of $i v Y$ protein. Pairs of dots between the lines indicate positions with the same amino acid in both sequences. Single connecting dots indicate amino acid substitutions which occur most frequently in evolution. A sequence in the putative mor polypeptide with potential for forming a helix-turn-helix DNA binding motif (see Discussion) is indicated with two vertical lines.

control for comparison with pSRW 226 because it has the same replicon and antibiotic resistance marker, but does not contain the mor gene. A marked difference in the level of expression from the chromosomal mor-lacZ fusion was observed depending on whether or not the mor-containing plasmid pSRW226 was present. Both SW1099(pKO6) and SW1099 exhibited similar $\beta$-galactosidase activities $(538 \pm 139$ and $589 \pm 121$ arbitrary units respectively), while SW1099(pSRW 226 ) exhibited a greatly reduced activity $(32 \pm 7)$. Thus, the presence of the mor gene was shown to bring about a 17- to 18-fold repression of the mor-lac $Z$ fusion, clearly indicating that the mor gene is autoregulated.

\section{Discussion}

The work described in this paper indicates that by manipulation of the mor gene it is possible to overcome the switching of an E. coli $\mathrm{K} 12$ strain between two forms with differing surface properties. It has been demonstrated that when a plasmid containing the mor gene, such as pSRW226, is introduced into a strain, this can result in it becoming fixed in a form exhibiting a glossy colony morphology and which does not undergo autoaggregation (Form 2). Alternatively, inactivation of the mor gene can fix a strain in Form 1. It should be borne in mind, however, that the phenotypes described in this 


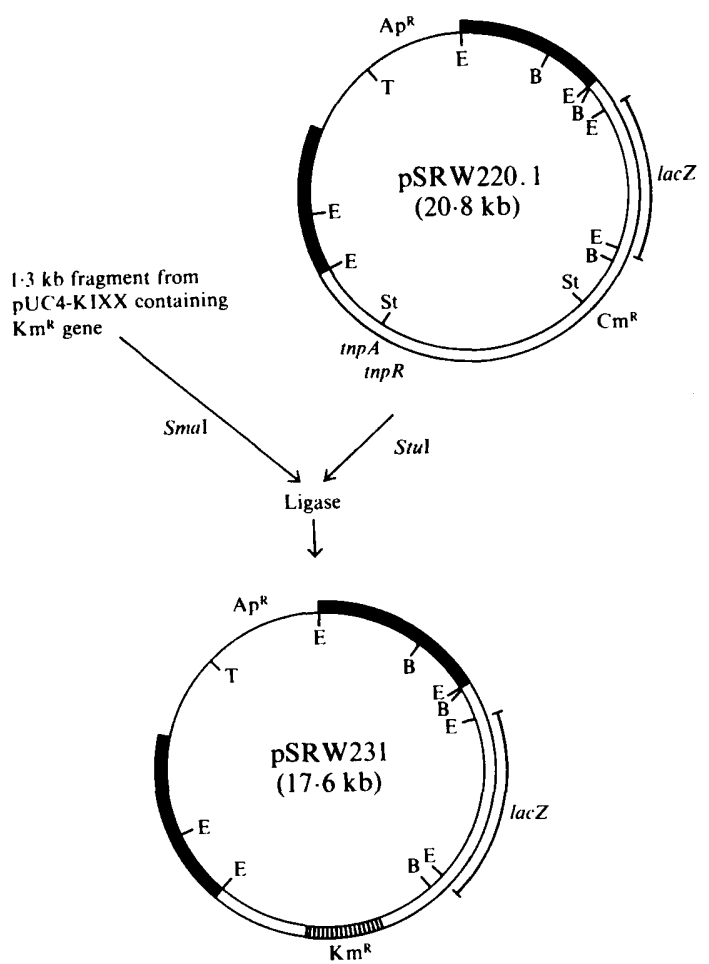

Fig. 5. Construction of pSRW231. $\square$, Chromosomally derived DNA; $\square$, Tn1737Cm-derived DNA; 四, pUC4-KIXX-derived DNA (Barany, 1985); -, pBR322-derived DNA. St and T represent the sites for the restriction enzymes $S t u \mathrm{I}$ and $T$ th $111 \mathrm{I} . \mathrm{Cm}^{\mathrm{R}}$ and $\mathrm{Km}^{\mathrm{R}}$ represent genes for chloramphenicol and kanamycin resistance. The resolvase and transposase genes of $T \mathrm{n} 1737 \mathrm{Cm}$ are represented by $\operatorname{tnp} R$ and $\operatorname{tnp} A$ respectively. During the construction of pSRW231 all of the tmpR coding sequence is removed along with about 450 amino acids from the $\mathrm{N}$-terminus of tnpA (Brown et al., 1985).

paper correspond to observations made with only one particular strain, BD1302. Preliminary experiments to determine the effect of inactivating mor gene activity in other $E$. coli strains have been done: these have shown that the phenotype associated with a mor mutation is dependent upon the genetic background into which it is introduced.

The mechanism by which pSRW226 can fix a strain in Form 2 is as yet unknown. One possibility is that expression of the mor gene is continually switching on and off as the result of a DNA inversion event similar to that which controls expression of the pilin gene ( $\operatorname{fim} A)$ in E. coli (Abraham et al., 1985). If this were the case the introduction of multiple copies of the mor gene on a plasmid would result in there being a very high probability that at least one copy of the gene would be in the active form at any given time. However no evidence for such switching was obtained using the mor-lacZ fusion. Further work is necessary to test this more rigorously. A second possibility is that there is another gene on the chromosome which is actually switching on and off and that the mor gene is involved in controlling this second gene in some way. For example, the mor gene could stimulate the switching of this second gene in one particular direction (either from off to on or from on to off). This latter mechanism would be similar to the action of the $f i m B$ and fimE regulatory genes which control the fimA gene (Klemm, 1986).

The results obtained suggest that the mor gene exerts its control over surface properties by encoding a regulatory protein rather than by directly encoding a surface component. The evidence for this comes from two lines of work. First, the sequence of the putative mor gene product shows a high level of homology to four regulatory proteins, ilv $Y$, cys $B$, lys $R$ and $m e t R$. Second, the mor gene is autoregulated and transcription from the mor promoter is repressed in the presence of excess mor gene product. In view of this evidence for a regulatory role, the putative mor protein sequence was searched using the method of Dodd \& Egan (1987) for sequences with potential for forming a helix-turn-helix DNA binding motif (Pabo \& Sauer, 1984). This analysis revealed a 20 -amino-acid sequence with a favourable score of 1523 (a score of over 1000 is taken to indicate a sequence with a potentially significant similarity to the helix-turn-helix motif). This sequence is located between residues 17 and 38 of the predicted mor protein sequence.

Another point worth noting is that all four of the proteins showing a high level of homology to the putative mor gene product are positive regulators of gene expression. It is therefore interesting to speculate that, in addition to acting as a negative regulator of its own expression, the mor gene product may exert its influence over cell surface properties by acting as a positive regulator.

The demonstration that the manipulation of the mor gene can affect both colony morphology and autoaggregation suggests that it must exert control over the production of one or more surface components. One surface component which would at first sight seem a prime candidate to explain the molecular basis of the surface properties observed is the lipopolysaccharide (LPS) component of the outer membrane. Wild-type $E$. coli can exist in two forms, known as $S$ and $R$, with different LPS structures. The results described in this paper cannot, however, be explained in terms of the existence of these $\mathbf{S}$ and $\mathbf{R}$ forms. This is because all of the strains which have been used in this study are derivatives of $E$. coli $\mathrm{K} 12$; this carries a $r f b$ mutation (Schmidt, 1973) which results in it permanently being in the $\mathbf{R}$ form. Thus it remains uncertain which surface components are responsible for the phenotypes described in this paper. 
We are grateful to Sandy Chisholm and Rachel Wood for excellent technical assistance, to Chris Thomas and Karen Warne for many helpful discussions, and to Lyn Gillham for typing the manuscript. This work was funded by the Biotechnology Advisory Committee of the Department of Trade and Industry.

\section{References}

Abraham, J. M., Freitag, C. S., Clements, J. R. \& Eisenstein, B. I. (1985). An invertible element of DNA controls phase variation of type 1 fimbriae in Escherichia coli. Proceedings of the National Academy of Sciences of the United States of America 82, 5724-5727.

BARANY, F. (1985). Single stranded hexameric linkers: a system for in-phase insertion mutagenesis and protein engineering. Gene 37, 111-123.

Birnboim, H. C. \& Doly, J. (1979). A rapid alkaline extraction procedure for screening recombinant plasmid DNA. Nucleic Acids Research 7, 1513-1523.

Brown, N. L., Winnie, J. N., Fritzinger, D. \& Pridmore, R. D. (1985). The nucleotide sequence of the tinpA gene completes the sequence of the Pseudomonas transposon Tn501. Nucleic Acids Research 13, 5657-5669.

DIDERICHSEN, B. (1980). $f u$, a metastable gene controlling surface properties of Escherichia coli. Journal of Bacteriology 141, 858-867.

DodD, I. B. \& EGAN, J. B. (1987). Systematic method for the detection of potential Cro-like DNA binding regions in proteins. Journal of Molecular Biology 194, 557-564.

HadField, C. (1987). Genomic library cloning with plasmid $\lambda$ and cosmid vectors. In Gene Cloning and Analysis - a Laboratory Guide, p. 95. Edited by G. J. Boulnois. Oxford: Blackwell Scientific Publications.

HaWley, D. K. \& MCCluRe, W. R. (1983). Compilation and analysis of Escherichia coli promoter DNA sequences. Nucleic Acids Research 11, 2237-2257.

Heller, K., ManN, B. J. \& Kadner, R. J. (1985). Cloning and expression of the gene for the vitamin $B_{12}$ receptor protein in the outer membrane of Escherichia coli. Journal of Bacteriology 161, 896-903.

JASIN, M. \& SCHImmel, P. (1984). Deletion of an essential gene in Escherichia coli by site specific recombination with linear DNA fragments. Journal of Bacteriology 159, 783-786.
KLEMM, P. (1986). Two regulatory fim genes, fimB and fimE, control the phase variation of type 1 fimbriae in Escherichia coli. EMBO Journal 5, $1389-1393$.

KozAK, M. (1983). Comparison of protein synthesis in prokaryotes, eukaryotes and organelles. Microbiology Reviews 47, 1-45.

Lipman, D. J. \& Pearson, W. R. (1985). Rapid and sensitive protein similarity searches. Science 227, 1435-1441.

MCKenney, K., ShimatKe, H., Court, D., Schmeissner, U., Brady, C. \& Rosenberg, M. (1981). In Gene Amplification and Analysis, vol 2, Analysis of Nucleic Acids by Enzymatic Methods, pp. 383-415. Edited by J. C. Chirikjiam \& T. S. Papas. Amsterdam: Elsevier.

MILleR, J. H. (1972). Experiments in Molecular Genetics. Cold Spring Harbor, NY: Cold Spring Harbor Laboratory.

NY, T. \& BJöRK, G. R. (1980). Cloning and restriction mapping of the trm $A$ gene coding for transfer ribonucleic acid (5-methyluridine)methyltransferase in Escherichia coli K12. Journal of Bacteriology 142, 371-379.

OSTROWSKI, J., JAGURA-BURdZY, G. \& KREDICH, N. M. (1987). DNA sequences of the cysB regions of Salmonella typhimurium and Escherichia coli. Journal of Biological Chemistry 262, 5999-6005.

Pabo, C. O. \& Sauer, R. T. (1984). Protein-DNA recognition. Annual Review of Biochemistry 53, 293-321.

Plamann, L. S. \& Stauffer, G. V. (1987). Nucleotide sequence of the Salmonella typhimurium metR gene and the metR-metE control region. Journal of Bacteriology 169, 3932-3937.

SCHMIDT, G. (1973). Genetical studies on the lipolysaccharide structure of Escherichia coli K12. Journal of General Microbiology 77, 151-160.

Stragier, P. \& Patte, J.-C. (1983). Regulation of diaminopimelate decarboxylase synthesis in Escherichia coli. III. Nucleotide sequence and regulation of the lysR gene. Journal of Molecular Biology 168 , 333-350.

UbBen, D. \& SChmitt, R. (1987). A transposable promoter and transposable promoter probes derived from $\mathrm{Tn} 1721$. Gene 53, 127134.

VARLEY, J. M. \& BoulnoIs, G. J. (1984). Analysis of a cloned colicin Ib gene: complete nucleotide sequence and implications for regulation of expression. Nucleic Acids Research 12, 6727-6739.

Walker, J. A., Allen, R. L., Falmagne, P., Johnson, M. K. \& BoulNoIs, G. J. (1987). Molecular cloning, characterization and complete nucleotide sequence of the gene for pneumolysin, and sulfhydryl-activated toxin of Streptococcus pneumoniae. Infection and Immunity 55, 1184-1189.

WeK, R. C. \& HATFIELD, G. W. (1986). Nucleotide sequence and in vivo expression of the ilv $Y$ and ilvC genes in Escherichia coli $\mathrm{K} 12$. Journal of Biological Chemistry 261, 2441-2450. 